\title{
POLA PERWALIAN SEBAGAI PEMBINAAN AKADEMIK, KEROHANIAN DAN KARAKTER MAHASISWA
}

\author{
I PutuAyubDarmawan \\ SekolahTinggiTeologi Simpson \\ putuayub.simpson@gmail.com \\ Deni Triastanti \\ SekolahTinggiTeologi Simpson \\ triastantideni@gmail.com
}

\begin{abstract}
This research was conducted to determine the pattern of student trusteeship as academic, spiritual and character development. The author uses a qualitative approach to obtain relevant information. The results showed that the guardianship of students was carried out in two forms, namely academic guidance and guidance that emphasized aspects of spirituality and character. Guardianship for academic guidance is carried out through the guidance of study plans, monitoring students on academic aspects, and providing motivation so that students experience academic improvement. Spiritual and character formation is carried out by holding joint prayers, guidance to get to know each group's spiritual gifts, personal and group counselling, and Bible study.
\end{abstract}

Keywords:

Control, Character, Academic, Student, Coaching

\begin{abstract}
Abstrak
Penelitian ini dilaksanakan untuk mengetahui pola perwalian mahasiswa sebagai pembinaan akademik, kerohanian, dan karakter. Penulis menggunakan pendekatan kualitatif untuk memperoleh informasi yang relevan. Hasil penelitian menunjukkan bahwa perwalian terhadap mahasiswa dilaksanakan dalam dua bentuk yaitu bimbingan yang bersifat akademik dan bimbingan yang menekankan aspek kerohanian dan karakter. Perwalian untuk bimbingan akademik dilaksanakan melalui bimbingan rencana studi, pemantauan mahasiswa pada aspek akademik, dan pememberian motivasi agar mahasiswa mengalami peningkatan secara akademik. Pembinaan rohani dan karakter dilaksanakan dengan mengadakan doa bersama, bimbingan untuk mengenal karunia rohani masingmasing kelompok, konseling pribadi dan grup, dan pendalaman Alkitab.
\end{abstract}

Kata Kunci:

Pewalian, Karakter, Akademik, Mahasiswa, Pembinaan 


\section{Pendahuluan}

Dalam tata kelola sebuah lembaga pendidikan pada sebuah sekolah, salah satu aspek yang menjadi komponen penting adalah pembinaan peserta didik. Pembinaan mahasiswa merupakan bagian dari layanan kemahasiswaan yang harus dilaksanakan sebagai upaya mencapai tujuan pendidikan. Antarini, Suryana, dan Sudemen menjelaskan bahwa selain berhak memperoleh layanan kegiatan akademik seperti pembelajaran, mahasiswa juga berhak untuk memperoleh pelayanan kegiatan kemahasiswaan. ${ }^{1}$ Secara umum layanan melalui perwalian dilaksanakan berupa bimbingan akademik, seperti yang dilakukan di beberapa perguruan tinggi. Tetapi beberapa perguruan tinggi mengadakan bentuk lain dalam kerangka layanan perwalian. Asriati dan Basri mengungkapkan bahwa perwalian merupakan kesempatan mahasiswa untuk melakukan konsultasi baik dalam bidang akademik maupun nonakademik. Tujuannya adalah untuk menunjang keberhasilan studi dan perkembangan akademik maupun karakter mahasiswa. ${ }^{2}$

Layanan pada tingkat program studi umumnya melibatkan dosen-dosen sebagai dosen wali. Dosen-dosen wali seperti yang dilakukan di IAIN Palu tampak berperan dalam upaya meningkatkan motivasi belajar mahasiswa, menjadi penasihat, model, pembimbing dan fasilitator mahasiswa dalam perkuliahan. ${ }^{3}$ Penelitian Asriati dan Basri juga menunjukkan bahwa peran dosen selain tugas akademik adalah membantu mahasiswa untuk membentuk karakter dan kompetensi mahasiswa menjadi calon sarjana yang unggul. Tugas tersebut dilaksanakan di luar tugas mengajar dalam bentuk kegiatan perwalian. ${ }^{4}$

Beberapa penelitian menunjukkan bahwa pelaksanaan perwalian mahasiswa oleh dosen bermanfaat untuk membantu kemajuan belajar mahasiswa. Penelitian Suma dan Sukandar menunjukkan bahwa pelaksanaan bimbingan perwalian mahasiwa efektif untuk membantu mahasiswa menjalani proses pendidikannya. ${ }^{5}$ Kemudian penelitian Rizki juga menunjukkan bahwa perwalian mahasiswa efektif untuk membantu mahasiswa dalam pendidikan. ${ }^{6}$ Penelitian yang dilakukan oleh Ariska juga menunjukkan bahwa pelaksanaan perwalian guna membimbing mahasiswa efektif untuk membantu mahasiswa menjadi lebih termotivasi menjalani pendidikan dan meningkatkan prestasi belajarnya. ${ }^{7}$ Karena kegiatan

${ }^{1}$ Lilik Antarini, I. Nyoman Mangku Suryana, and I. Wayan Sudemen, “Tingkat Kepuasan Layanan Mahasiswa Universitas Warmadewa Tahun 2017," SINTESA (Jurnal Ilmu Sosial dan Ilmu Politik) 8, no. 1 (2017): 14.

${ }^{2}$ Nuraini Asriati and Muhammad Basri, "Profil Kinerja Dosen Jurusan Pendidikan IPS FKIP Untan," Guru Membangun 30, no. 1 (2015): 39.

${ }^{3}$ Andi Anirah, "Mekanisme Layanan Bimbingan Akademik Dalam Meningkatkan Motivasi Belajar Mahasiswa Di Institut Agama Islam Negeri Palu," Istiqra: Jurnal Hasil Penelitian 4, no. 1 (2016): 49-80.

${ }^{4}$ Asriati and Basri, "Profil Kinerja Dosen Jurusan Pendidikan IPS FKIP Untan."

${ }^{5}$ Enang Suma and Aan Sukandar, "Efektivitas Pelaksanaan Bimbingan Perwalian Terhadap Sikap Belajar Mahasiswa Pendidikan Teknik Mesin FPTK UPI Bandung," file.upi.edu (n.d.), accessed April 8, 2020, https://www.academia.edu/1173062/EFEKTIVITAS_PELAKSANAAN_BIMBINGAN_PERWALIA N_TERHADAP_SIKAP_BELAJAR_MAHASISWA_PENDIDIKAN_TEKNIK_MESIN_FPTK_UPI_BA NDUNG.

${ }^{6}$ Mohammad Tri Rizki, “Evaluasi Terhadap Efektivitas Pembimbingan Online Untuk Perwalian Mahasiswa Jurusan Kurtekdik, FIP, UNNES” (Under Graduates thesis, Universitas Negeri Semarang, 2015), accessed April 6, 2020, https://lib.unnes.ac.id/23199/.

7Ita Ariska, "Peran Dosen Pembimbing Akademik dalam Meningkatkan Motivasi Belajar Mahasiswa: Penelitian Di Fakultas Dakwah dan Komunikasi Universitas Islam Negeri Sunan Gunung Djati Bandung Angkatan 2012" (diploma, UIN Sunan Gunung Djati Bandung, 2015), accessed April 9, 2020, http://digilib.uinsgd.ac.id/5145/. 
perwalian mahasiswa memiliki peranan penting terhadap kemajuan belajar mahasiswa, penulis memandang perlu juga diteliti tentang pola perwalian yang dilaksanakan pada sebuah perguruan tinggi keagamaan Kristen.

Darmawan dan Sujoko pernah melakukan penelitian terhadap kepuasan layanan pada mahasiswa di STT Simpson. Dari hasil penelitian tampak bahwa layanan yang diberikan dirasa cukup memuaskan oleh mahasiswa yang diteliti. ${ }^{8}$ Mencermati penelitian tersebut, penulis memandang perlu dilakukan penelitian yang lebih mendalam pada kegiatan pembinaan mahasiswa STT Simpson. Oleh sebab itu penulis meneliti pola perwalian sebagai pembinaan akademik dan karakter mahasiswa STT Simpson. Rumusan masalah dalam penelitian ini adalah bagaimana pola perwalian sebagai pembinaan akademik, kerohanian dan karakter mahasiswa di STT Simpson? Tujuan penelitian ini adalah untuk memaparkan tentang pola perwalian sebagai pembinaan akademik, kerohanian dan karakter mahasiswa di STT Simpson.

\section{Metode Penelitian}

Pendekatan penelitian yang digunakan dalam penelitian ini adalah kualitatif. Penulis menggunakan pendekatan kualitatif karena penulis ingin memperoleh informasi secara natural dan apa adanya. Hal itu dibutuhkan agar proses penelitian berjalan dalam kondisi alamiah, tanpa pengkondisian atau tindakan dari peneliti. Jenis penelitian ini menurut Creswell, Zaluchu, maupun Purwanto tepat digunakan untuk memperoleh data yang alamiah. ${ }^{9}$

Penulis mengumpulkan data melalui pemeriksaan dokumen, dan observasi partisipatif. Penulis melakukan wawancara pada beberapa mahasiswa yang mengalami masalah dalam prestasi akademik, sehingga memperoleh informasi terkait pembinaan terhadap mereka. Dokumen yang diteliti adalah jadwal kegiatan pembinaan, materi pembinaan, dokumen perwalian akademik, dan dokumen pendukung di bagian akademik. Observasi dilakukan dengan mencermati kegiatan pembinaan mahasiswa pada semester Gasal 2019/2020. Penelitian ini dilaksanakan pada Sekolah Tinggi Teologi Simpson Ungaran. Tempat penelitian ini dipilih karena di STT Simpson terdapat kegiatan perwalian mahasiswa yang dilaksanakan sebagai bentuk pembinaan akademik, karakter dan kerohanian. Data yang dikumpulkan dari dokumen dan observasi kemudian dianalisis sehingga memperoleh garis besar pola perwalian mahasiswa. Data-data tersebut kemudian disajikan secara deskriptif denga melakukan sintesa dari hasil studi dokumen dan observasi. Dalam bagian hasil dan pembahasan, penulis melakukan elaborasi dengan sumber-sumber literatur yang relevan untuk mendialogkan hasil penelitian dengan teori.

\section{Hasil dan Pembahasan}

Pola perwalian di STT Simpson dilaksanakan dalam dua bentuk yaitu bimbingan akademik kemudian pembinaan rohani dan karakter. Dari hasil observasi dan pemeriksaan

8I. Putu Ayub Darmawan and Edi Sujoko, “Survei Terhadap Kepuasan Mahasiswa Pada Kualitas Layanan Di STT Simpson Ungaran, Semarang, Jawa Tengah," Satya Widya 33, no. 1 (2017): 45-53.

9 John W. Creswell, Research Design: Pendekatan Kualitatif, Kuantitatif, Dan Mixed (Yogyakarta: Pustaka Pelajar, 2013); Sonny Eli Zaluchu, "Strategi Penelitian Kualitatif dan Kuantitatif Di Dalam Penelitian Agama," Evangelikal: Jurnal Teologi Injili dan Pembinaan Warga Jemaat 4, no. 1 (January 31, 2020): 28-38; Hary Purwanto, "Manfaat Penelitian Untuk Perkembangan Gereja," in Prosiding Seminar Nasional Pendidikan Agama Kristen STT Simpson Tahun 2016 Tema: Strategi Pembinaan Jemaat Untuk Meningkatkan Kehidupan Jemaat (presented at the Seminar Nasional Pendidikan Agama Kristen \& call for papers, Ungaran: Sekolah Tinggi Teologi Simpson, 2016). 
beberapa dokumen, dua bentuk tersebut dilaksanakan sebagai bagian dalam membina mahasiswa.

\section{Bimbingan Akademik}

Proses perwalian ini dilakukan dalam rentan waktu selama masa studi. Dalam proses perkuliahan mahasiswa pasti selalu ada hambatan-hambatan baik secara akademik maupun nonakademik. Bimbingan akademik merupakan kegiatan yang harus dilakukan di sebuah Perguruan Tinggi. Fungsi bimbingan menurut Syaifudin untuk mencapai kesejahteraan mahasiswa guna mencapai apa yang dicita-citakannya. ${ }^{10}$ Rizki mengatakan, bimbingan di perguruan tinggi merupakan usaha membantu mahasiswa untuk mengembangkan diri dalam mengatasi masalah akademik maupun nonakademik. ${ }^{11}$ Bimbingan akademik dosen dan mahasiswa merupakan suatu kebutuhan yang harus dilakukan untuk memfasilitasi dan menjadi bagian dari tugas seorang dosen (Permendikbud no.49 Tahun 2014).

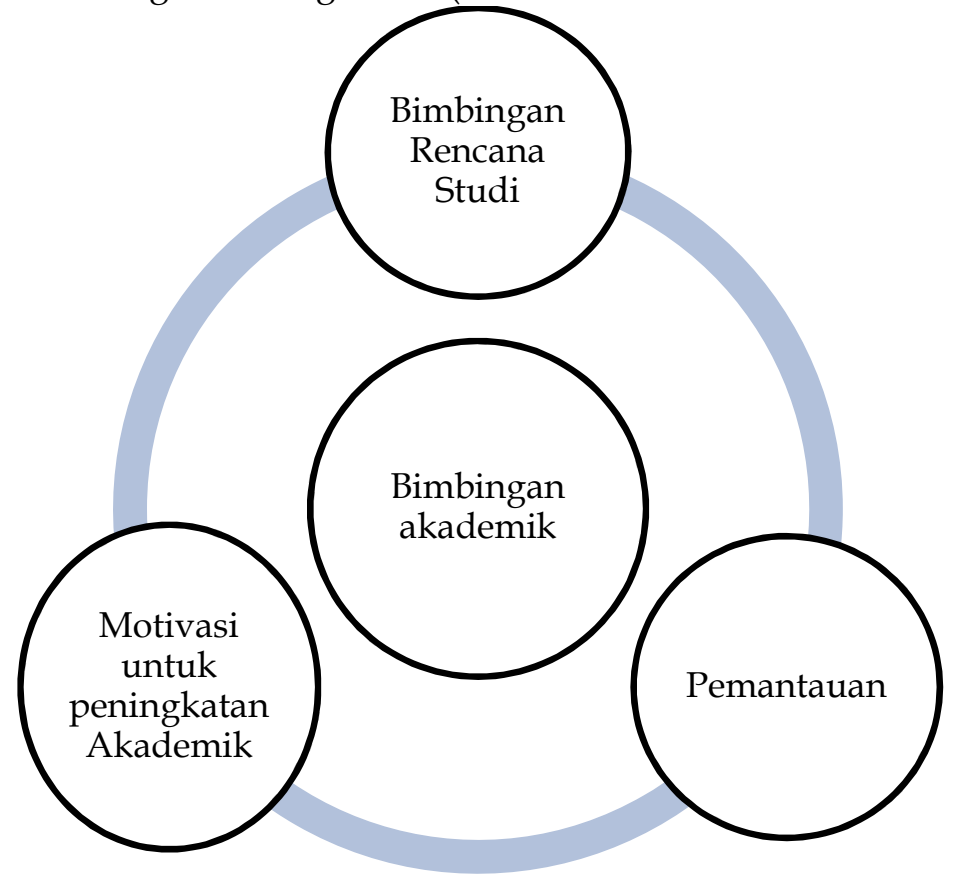

Gambar 1. Kegiatan Bimbingan Akademik

Bimbingan akademik yang dilakukan di STT Simpson secara keseluruhan diikuti oleh kurang lebih 10-15 mahasiswa perwalian di tiap-tiap wali akademik. Pelaksanaan dari bimbingan tersebut, sama halnya dengan fungsi perwalian yaitu membantu mahasiswa dalam kebutuhan akademik selama masa studi. Dengan tujuan, mahasiwa dapat menyelesaikan perkuliahannya tepat waktu, dengan mengurangi hambatan-hambatan yang terjadi pada mahasiswa.

Pertama, bimbingan rencana studi. Salah satu bimbingan akademik yang diberikan pada mahasiswa STT Simpson adalah bimbingan rencana studi yang dilaksanakan dua kali yaitu saat pra registrasi yang memberikan usulan rencana pengambilan matakuliah pada

${ }^{10}$ M. Fakhrur Saifudin, "Pola Pembimbingan Akademik Dosen Wali Sebagai Upaya Efektivitas Masa Studi Mahasiswa," JMKSP (Jurnal Manajemen, Kepemimpinan, dan Supervisi Pendidikan) 3, no. 2 (2018): 149-160.

${ }^{11}$ Mohammad Rizki, “Evaluasi Terhadap Efektifitas Pembimbingan Online Untuk Perwalian Mahasiswa Jurusan Kurtedik, FIP, UNNES” (other, Universitas Negeri Semarang, 2015). 
semester depannya dan saat registrasi yaitu mengajukan matakuliah yang akan ditempuh dalam semester yang berjalan. Dalam proses ini, dosen wali mencermati matakuliah yang telah ditempuh mahasiswa, mata kuliah yang belum ditempuh dan belum tuntas, kemudian indeks prestasi kumulatif, rencana studi mahasiswa, dan hal lain yang dipandang perlu. Upaya tersebut dilakukan sebagai bentuk untuk memberikan layanan terbaik bagi mahasiswa sehingga mahasiswa dapat menyelesaikan pendidikan dengan baik. Hal ini sejalan dengan apa yang dikemukakan oleh Patimah bahwa dengan dilaksanakan pembimbing akademik diharapkan perguruan tinggi mampu memberikan layanan kepada mahasiswa bimbingannya sebagai upaya keberhasilan studi.12 Oleh sebab itu dosen memegang peranan penting untuk mengarahkan mahasiswanya dalam menjalani masa studi sesuai dengan kemampuan masing-masing mahasiswa. Untuk menjalankan kegiatan ini, Bidang Administrasi Akademik Kemahasiswaan (BAAK) menyediakan dokumendokumen yang diperlukan oleh dosen untuk memberikan layanan perwalian yang terbaik bagi mahasiswa.

Selain itu, pembaharuan informasi di laman siakad.sttsimpson.ac.id terus dilakukan agar mahasiswa dapat memantau progres pendidikannya dan dosen wali dapat memanfaatkan informasi ini untuk memberikan layanan perwalian. Data-data yang tersedia di laman siakad.sttsimpson.ac.id merupakan sumber informasi yang menjadi pertimbangan pemberian saran, pengambilan keputusan, dan rencana studi mahasiswa.Proses bimbingan rencana studi mahasiswa dilakukan langsung oleh dosen wali dan dilakukan secara individu antara dosen dan mahasiswa. Salah satu yang menjadi pertimbangan bahwa proses ini tidak dilakukan secara kelompok karena dosen mencoba mencermati masalah-masalah akademik masing-masing mahasiswa. Kesempatan ini digunakan pula untuk mencermati masalah kesulitan belajar mahasiswa dan berbagai kendala lain yang berkaitan dengan akademik tetapi sifatnya cukup pribadi.

Pola pembimbingan rencana studi sebagaimana dikemukakan di atas, hampir sama dengan pola-pola pembimbingan yang dilakukan di beberapa perguruan tinggi lainnya. Penulis membandingkan dengan penelitian Antarini, Suryana, dan Sudemen di Universitas Warmadewa, kemudian penelitian Anirah di IAIN Palu, kemudian penelitian Suma dan Sukandar di FPTK UPI Bandung, tampak bahwa pola bimbingan rencana studi mahasiswa di STT Simpson hampir sama. ${ }^{13}$ Hanya perbedaannya dalam proses ini tampaknya dosen STT Simpson menekankan nilai-nilai kekristenan ketika mahasiswa mengalami kesulitan dalam aspek akademik, seperti meneguhkan iman mahasiswa, memberi dorongan berdasarkan ayat-ayat Alkitab, dan mendoakan mahasiswa.

Kedua, pemantauan. Upaya pemantauan dosen wali terhadap mahasiswa perwaliannya juga penting untuk dilakukan. Hal tersebut guna mengetahui peningkatan atau penurunan prestasi mahasiswa. Syaifudin mengatakan, sebagai dosen wali sangat perlu strategi dalam melakukan pemantauan seiring dengan kesibukan-kesibukan dosen.14 Peranan wali akan sangat berpengaruh dalam mahasiswa beriteraksi menyelesaikan perkuliahan. Maka dari itu, selain pendampingan dan pemantauan dalam proses perkuliahan, juga perlu pemantauan terhadap mahasiswa dalam kehidupan sosialnya.

12Siti Patimah, "Hubungan Peran Bimbingan Akademik, Kecerdasan Intelektual, dan Minat dengan Prestasi Belajar," Media Informasi 11, no. 1 (July 1, 2015): 20-26.

${ }^{13}$ Antarini, Suryana, and Sudemen, "Tingkat Kepuasan Layanan Mahasiswa Universitas Warmadewa Tahun 2017"; Anirah, "Mekanisme Layanan Bimbingan Akademik Dalam Meningkatkan Motivasi Belajar Mahasiswa Di Institut Agama Islam Negeri Palu"; Suma and Sukandar, "Efektivitas Pelaksanaan Bimbingan Perwalian Terhadap Sikap Belajar Mahasiswa Pendidikan Teknik Mesin FPTK UPI Bandung." Mahasiswa."

${ }^{14}$ Saifudin, "Pola Pembimbingan Akademik Dosen Wali Sebagai Upaya Efektivitas Masa Studi 
Melihat bahwa kesuksesan akademik juga akan mempengaruhi kesuksesan di sosial masyarakat, secara khusus sebagai mahasiswa teologi, akan mempengaruhi pelayananpelayanan ke depannya.

Pemantauan terhadap mahasiswa-mahasiswa dilakukan oleh dosen sesuai dengan kreativitas masing-masing dosen. Ariska mengungkapkan bahwa kreativitas atau kecerdasan dosen dalam memberikan bimbingan merupakan salah satu faktor yang mendorong terjadinya peningkatan capaian belajar mahasiswa. ${ }^{15}$ Tidak ada sebuah panduan khusus yang digunakan untuk memantau mahasiswa perwalian di STT Simpson, itu sebabnya masing-masing dosen melakukan pemantauan terhadap mahasiswa menggunakan kreativitas masing-masing. Walau demikian, dosen wali umumnya memperoleh informasi dari pengawas asrama yang berkaitan dengan kehidupan sosial, kemudian informasi dari sekretaris prodi yang berkaitan dengan aktivitas perkuliahan, maupun input dari dosen matakuliah yang mencermati ada masalah pada mahasiswanya. Dosen wali juga mencermati apakah pergaulan mahasiswa di dalam asrama, maupun interaksi di kelas dan di luar kelas maupun asrama berdampak pada peningkatan prestasi akademik mahasiswa.

Ketiga, motivasi untuk peningkatan akademik. Selain daripada pemantauan perkembangan belajar, diperlukan juga pendampingan motivasi belajar mahasiswa. Menurut Syaifudin, maksud dari bimbingan individual ini adalah memberikan ruang dan waktu konsultasi khusus bagi mahasiswa untuk mendapatkan solusi akademik yang bersifat pribadi. ${ }^{16}$ Hal yang sama diungkapkan Anindar bahwa perwalian akademik dituntut untuk menyediakan waktu untuk berkomunikasi, membimbing, memotivasi serta mencarikan jalan keluarnya. ${ }^{17}$ Demikian pula dikatakan oleh Asriati dan Basri bahwa dalam perwalian akademik bagian terpentingnya adalah memberikan saran, motivasi, memberikan informasi yang mengarah pada terjadinya peningkatan akademik mahasiswa. ${ }^{18}$ Dari observasi yang penulis lakukan di STT Simpson tampak bahwa melalui bimbingan individu, dosen dapat memberikan dorongan maupun membantu pemecahan masalah yang dialami oleh mahasiswa. Ada kalanya mahasiswa kesulitan memecahkan masalahnya sendiri dan membutuhkan bantuan dosen yang memberikan masukan.

Penulis melakukan wawancara pada beberapa mahasiswa yang secara akademik membutuhkan dorongan dari orang lain. Wawancara ini dilakukan untuk mengetahui bagaimana dosen wali memberikan motivasi pada masing-masing informan. Mahasiswa AI dalam wawancara mengatakan pada registrasi awal semester dosen memberikan motivasi dengan menuliskan pesan "Tingkatkan" pada form registrasi yang diisi oleh dosen. Sementara wawancara pada mahasiswa PK tampak bahwa wali akademik memberikan motivasi secara lisan dengan mendorong agar lebih banyak belajar lagi. Wawancara pada mahasiswa $\mathrm{F}$ yang sedang menjalani masa disiplin kampus, motivasi yang disampaikan wali akademik dengan memberi kata-kata "walaupun menjalani masa disiplin, terus berjuang, tingkatkan belajar." Kemudian wawancara pada mahasiswa MK, tampak bahwa dosen wali memberikan dorongan agar meningkatkan kualitas belajarnya. Dosen memberikan motivasi agar mahasiswa MK terus meningkatkan capaian belajarnya. Mahasiswa NK mengungkapkan bahwa dosen wali memberikan motivasi baik lisan maupun tertulis di form registrasi, nasihat yang selalu diulang-ulang adalah " terus berjuang!". Selain itu tampak

\footnotetext{
${ }^{15}$ Ariska, "Peran Dosen Pembimbing Akademik dalam Meningkatkan Motivasi Belajar Mahasiswa."

${ }^{16}$ Saifudin, "Pola Pembimbingan Akademik Dosen Wali Sebagai Upaya Efektivitas Masa Studi Mahasiswa."

17Jum Anidar, "Peran Penasehat Akademik Terhadap Kesuksesan Mahasiswa di Perguruan Tinggi," Al-Ta lim Journal 19, no. 3 (November 21, 2012): 216-223.

${ }^{18}$ Asriati and Basri, "Profil Kinerja Dosen Jurusan Pendidikan IPS FKIP Untan," 39.
} 
bahwa mahasiswa juga diberikan dorongan atau motivasi dengan menggunakan nilai-nilai kekristenan. Pola ini pada dasarnya merupakan sebuah pola pemuridan dari seorang mentor agar seorang yang dimuridkan mengalami kemajuan secara rohani. ${ }^{19}$

Dari paparan di atas tampak bahwa mahasiswa membutuhkan dorongan yang timbul dari orang lain agar dapat memaksimalkan diri mereka dalam bidang yang sedang ditekuninya. Penulis membandingkan dengan temuan penelitian Ariska bahwa pemberian dorongan melalui bertanya, evaluasi, apresiasi, saran, mengingatkan, anjuran, memberi masukan, motivasi, reward atau punishment, komunikasi pendekatan persuasif, himbauan, menumbuhkan kesadaran, referral, dan orientasi membantu untuk mendorong mahasiswa meningkatkan motivasi belajarnya. ${ }^{20}$ Beberapa tindakan yang disebutkan oleh Ariska tampak dilakukan oleh dosen wali di STT Simpson, dengan demikian motivasi untuk meningkatkan capaian belajar telah dilaksanakan. Riniwati mengungkapkan bahwa peran dosen dalam memberikan motivasi berperan penting dalam kemajuan belajar. ${ }^{21}$ Itu sebabnya pemberian motivasi perlu terus dilakukan baik secara formal maupun non formal.

\section{Pembinaan Rohani dan Karakter}

Di STT Simpson, selain pembinaan komunitas mahasiswa dalam bentuk perwalian akademik, juga dilakukan melalui pembinaan rohani. Dosen wali memiliki peran ganda, sebagai dosen wali akademik sekaligus sebagai dosen pengampu pembinaan rohani. Pembinaan rohani dan karakter mahasiswa di STT Simpson dilaksanakan setiap seminggu sekali pada hari Jumat yang disebut dengan Kelompok Pembinaan. Dalam kegiatan tersebut, anggota kelompok sama dengan anggota perwalian akademik. Akan tetapi dalam kelompok pembinaan ini, pembelajaran dikemas dengan situasi yang santai. Bahkan sebagian besar, kelas kelompok pembinaan ini dilakukan diluar kelas. Tujuan dari diadakannya kelas pembinaan ini agar terjalin hubungan yang lebih dekat satu sama lain dalam kelompok.

${ }^{19}$ I. Putu Ayub Darmawan, "Murid Yang Memuridkan," in Melaksanakan Amanat Agung Di Abad 21 (Ungaran: Sekolah Tinggi Teologi Simpson, 2017). Mahasiswa."

${ }^{20}$ Ariska, "Peran Dosen Pembimbing Akademik dalam Meningkatkan Motivasi Belajar

${ }^{21}$ R. Riniwati, Motivasi, Prestasi Dan Evaluasi Belajar (Ungaran: Sekolah Tinggi Teologi Simpson, 2016). 


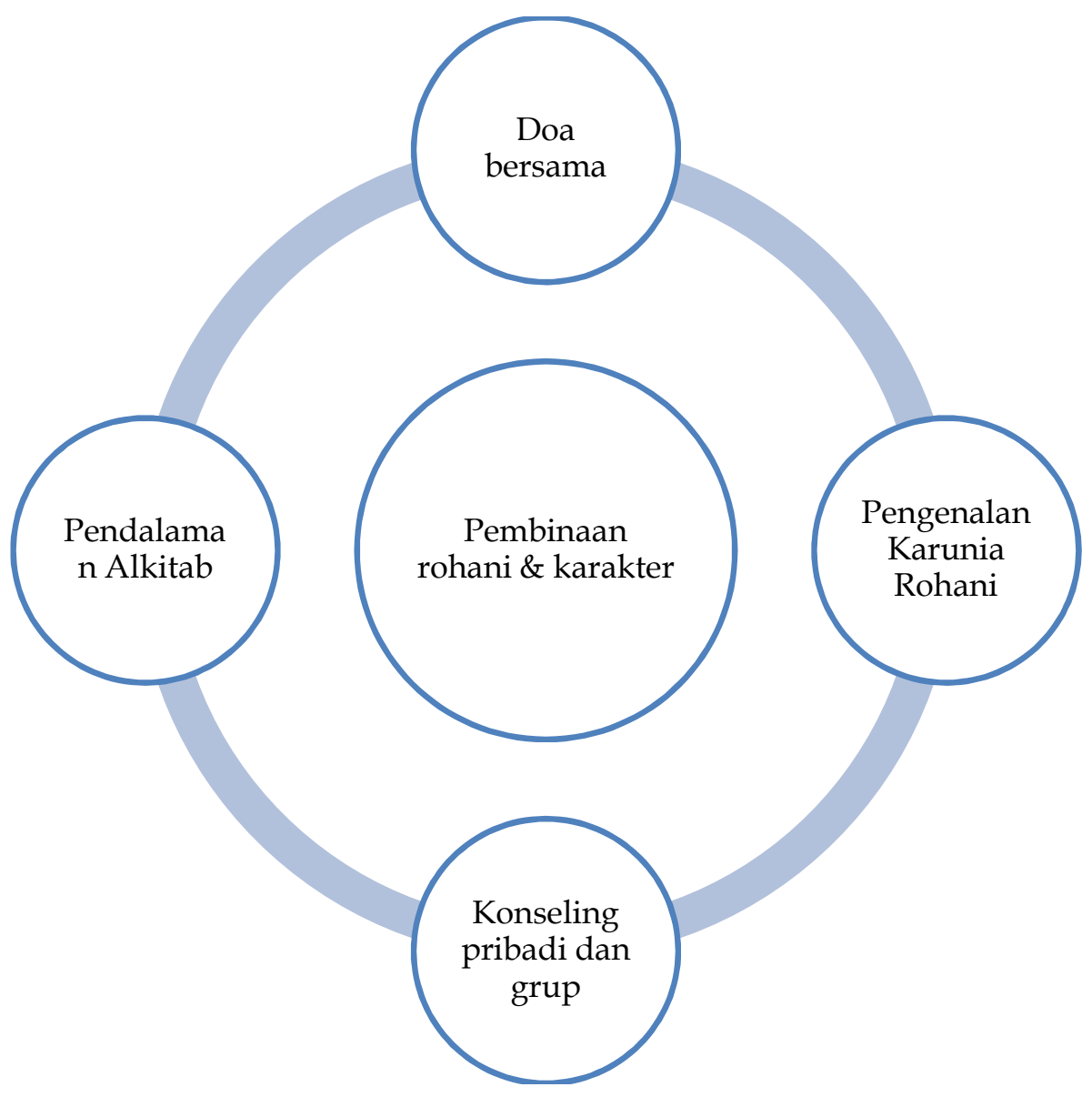

\section{Gambar 2. Kegiatan Pembinaan Rohani dan Karakter}

Sebagai perguruan tinggi teologi, pembinaan rohani dan karakter sangat penting dilakukan. Simanjuntak mengatakan bahwa pembinaan harus dilakukan sebagaimana Yesus dalam keempat Injil melakukan pembinaan. Bahkan dalam perjalanan kisah rasul, pembinaan merupakan tiang dasar berdirinya gereja. ${ }^{22}$ Rice mengungkapkan bahwa pembinaan rohani merupakan proses mengarahkan individu atau kelompok besar atau kecil merasakan bahwa Allah yang telah membimbing, menuntun dalam setiap aspek kehidupannya. ${ }^{23}$ Hal yang serupa diungkapkan oleh Selan, pembinaan penting adanya karena berkenaan dengan suatu proses menghubungkan kehidupan serta mendewasakan ke dalam Kristus melalui Roh Kudus. ${ }^{24}$ Sianturi dan Sidabutar mendeskripsikan bahwa kehidupan kerohanian yang baik dan benar ditandai dengan sebuah pemahaman dan ketaatan dalam menjalankan nilai-nilai agama dengan baik tanpa dipengaruhi oleh situasi dan kondisi apapun. Dalam keadaan apa saja, seharusnya orang yang taat beragama mampu

22Junihot M. Simanjuntak, “Implikasi Konsep Dan Desain Kurikulum Dalam Tugas

Pembinaan Warga Jemaat," Jurnal Jaffray 12, no. 2 (October 2, 2014): 251-272.

${ }^{23}$ Howard Rice, Manajemen Umat (Bandung: Kalam Hidup, 2006). 58.

${ }^{24}$ Ruth Selan, Pembinaan Warga Gereja (Bandung: Kalam Hidup, 2006). 15. 
menempatkan diri dan memiliki pengendalian diri agar tidak terjerumus kepada perbuatan yang bertentangan dengan nilai-nilai agama. ${ }^{25}$

Maka dari itu, pembinaan rohani dan karakter memiliki peran penting bagi mahasiswa karena pembinaan rohani mengantar, mendidik mahasiswa ke dalam pertumbuhan iman serta berkarakter seperti Kristus. Selain daripada hal tersebut, mahasiswa dapat memahami serta mewujudkannya dalam kehidupan terhadap sesama. Sehingga mahasiswa teologi memilki kekuatan untuk mengaplikasikan ke dalam pelayanannya di masa yang akan datang baik di gereja maupun di masyarakat.

Beberapa kegiatan yang dilaksanakan dalam pembinaan rohani dan karakter adalah sebagai berikut: pertama, doa bersama. Dalam proses pembinaan rohani, kegiatan berdoa bersama dalam grup juga menjadi bagian penting. Hal tersebut dikoordinir oleh dosen pembina, dan mahasiswa saling menyampaikan pergumulannya. Kekuatan doa dalam kelompok kecil ini sangat membantu mahasiswa dalam pertumbuhan spiritualitas. Observasi yang penulis lakukan dan mencermati jadwal kegiatan pembinaan, kegiatan doa dilakukan dengan dua cara yaitu pertama dengan membuat jadwal khusus untuk doa dan cara kedua adalah pada akhir kegiatan pembinaan, anggota kelompok pembinaan menyampaikan pergumulan masing-masing kemudian didoakan bersama dalam kelompok. Selain doa untuk pergumulan pribadi, anggota pembinaan juga mendoakan mahasiswa lain yang sedang berada dalam masa KKL, sedang menulis skripsi, hingga mendoakan kondisi bangsa dan Negara. Melalui kegiatan doa, anggota pembinaan juga menyampaikan syukur atas pertolongan Tuhan dalam kehidupan pribadi dan keluarga mereka.

Melihat sisi pentingnya doa, Sulistio mengatakan, doa merupakan suatu persekutuan antara manusia dengan Tuhan untuk memohon agar apa yang Tuhan telah janjikan dapat terpenuhi di dalam kehidupan orang percaya. ${ }^{26}$ Searah dengan ini, Brill mengatakan doa merupakan persekutuan pribadi antara manusia dengan Allah yang di dalamnya seseorang meninggikan, menyembah, mengucap syukur bahkan mengaku dosa serta memohon sesuatu kepada Allah. ${ }^{27}$ Kegiatan doa dalam kelompok pembinaan di STT Simpson, mahasiswa dibina untuk dapat menyadari pentingnya kehidupan doa kemudian membangun persekutuan dengan sesama melalui saling mendoakan dan membangun persekutuan dengan Tuhan dengan memanjatkan pergumulan doa mereka. Kegiatan doa bersama menjadi cara STT Simpson untuk memperlengkapi mahasiswa tidak hanya pada sisi intelektual tetapi juga didorong untuk memiliki hubungan yang benar tentang Allah dalam kehidupan doa.

Persekutuan doa dalam kelompok pembinaan di STT Simpson, membantu mahasiswa memperoleh kekuatan rohani. Sama halnya yang dilakukan para rasul dalam gereja mula-mula, orang percaya mengalami penganiayaan, doa dipanjatkan bersama-sama kepada Allah merupakan doa yang mempunyai kesatuan hati dan pikiran. ${ }^{28}$ Kesatuan doa inilah yang memberikan kekuatan supranatural mahasiswa dalam menghadapi pelayananpelayanan di lapangan, maupun kesulitan-kesulitan dalam proses pendidikan yang harus diikuti selama masa studi di STT Simpson.

${ }^{25}$ RJ Natongam Sianturi and Hasudungan Sidabutar, "Perilaku Seksual Pranikah Di Kalangan Mahasiswa Program Studi Pendidikan Agama Kristen," Jurnal Ilmiah Religiosity Entity Humanity (JIREH) 1, no. 1 (June 18, 2019): 72-86.

${ }^{26}$ Thio Christian Sulistio, "Peran Roh Kudus di dalam Doa menurut John Calvin," Veritas :

Jurnal Teologi dan Pelayanan 2, no. 2 (October 1, 2001): 177-184.

27Wesley Brill, Dasar Yang Teguh (Bandung: Kalam Hidup, 2015), 242.

${ }^{28}$ Daniel Sutoyo, "Allah Memanggil Umat-Nya Untuk Menjadi Gereja Yang Tekun Berdoa Menurut Kisah Para Rasul 4: 23 - 31," DUNAMIS: Jurnal Teologi dan Pendidikan Kristiani 1, no. 1 (September 1, 2016): 52-73. 
Kedua, pendalaman Alkitab. Alkitab merupakan wahyu Allah, dikerjakan oleh Roh Kudus agar berita keselamatan Allah melalui Yesus Kristus dapat disampaikan kepada semua orang. ${ }^{29}$ Alkitab menurut Katarina dan Darmawan sangat penting dalam pembentukan kehidupan Kristen. Hal ini tampak pada masa reformasi gereja yang menekankan sola scriptura dalam kehidupan Kristen. Penekanan sola scriptura menjadikan perubahan pola pikir yang akhirnya mempengaruhi tindakan praktis. ${ }^{30}$

Pendalaman Alkitab juga menjadi bagian pelaksanaan kegiatan pembinaan rohani. Kegiatan ini biasanya dilakukan dengan meneliti firman Tuhan antar pribadi sesuai dengan kegiatan praktis sehari-hari. Dalam pembinaan rohani hal ini dilakukan, melihat bahwa pendalaman Alkitab tidak sama dengan mendengarkan khotbah. Pendalaman Alkitab disampaikan secara dialog, dimana mahasiswa saling mendiskusikan firman Tuhan, sehingga dapat berbagi pengalaman atau komentar satu dengan yang lainnya. Menurut Sudjono, pengajar bertanggungjawab melatih umat Allah agar tidak hanya hidup berdasarkan inspirasi firman Allah, tetapi juga pada pengajaran firman Tuhan. ${ }^{31}$ Bahkan Hartono menekankan pentingnya tujuan pendalaman Alkitab yakni: 1) agar tidak menafsirkan Alkitab dengan sembarangan; 2) mendorong agar setiap orang memiliki kehendak yang murni berdasarkan firman Tuhan; 3) membawa hidup sepenuhnya dikendalikan oleh Roh Kudus. 4) menyadari bahwa Alkitab kaya dalam pengajaran (2 Tim. 3:16-17).32

Pendalaman Alkitab dilakukan sebagai wujud pemuridan. Selain itu juga sebagai tindak lanjut mengajar orang Kristen menjalin relasi dengan Allah dalam firman-Nya. "Jadilah sama seperti bayi yang baru lahir, yang selalu ingin akan air susu yang murni dan rohani, supaya olehnya kamu bertumbuh" (1 Ptr 2:2). Melalui pendalaman Alkitab dapat mengarahkan serta mengajarkan seseorang memahami rencana Allah bagi dirinya. Maka dari itu, dalam pembinaan rohani yang dilakukan di STT Simpson, pendalaman Alkitab dilakukan untuk mengarahkan mahasiswa ke dalam kehidupan kerohanian yang baik dan dewasa dalam iman. Selain itu pendalaman Alkitab juga melatih mahasiswa agar dapat mengajarkannya di ladang pelayanan.

Ketiga, pengenalan karunia rohani. Setiap orang Kristen dianugerahi karunia rohani sebagai perlengkapan tubuh Kristus (1 Pet 4:10). Menurut Stedman, karunia rohani diartikan sebagai kapasitas untuk pelayanan yang diberikan kepada setiap orang Kristen yang sejati tanpa perkecualian dan tidak dimiliki oleh orang sebelum ia menjadi Kristen. Hal yang sama diungkapkan oleh Greig dan Springer bahwa karunia roh adalah suatu yang layak mendapat penekanan dalam pelayanan gereja. Sutoyo mengatakan, karunia roh adalah tanda-tanda kerajaan dan pemerintahan Allah di dalam Kristus. ${ }^{33}$ Peter Wagner mengatakan perlengkapan istimewa yang diberikan oleh Roh Kudus kepada tiap-tiap anggota tubuh

${ }^{29}$ Oktavia Amba, "Implementasi Pemuridan Kontekstual Untuk Meningkatkan Minat Remaja Kristen Dalam Membaca Alkitab" (IAKN Tooraja, 2020), accessed April 8, 2020, https://osf.io/q54ra/.

${ }^{30}$ K. Katarina and I. Putu Ayub Darmawan, "Implikasi Alkitab Dalam Formasi Rohani Pada Era Reformasi Gereja," EPIGRAPHE: Jurnal Teologi dan Pelayanan Kristiani 3, no. 2 (2019): 81-93.

${ }^{31}$ Andreas Sudjono, "Pentingnya Karunia Pengajar Di Dalam Gereja," Jurnal Antusias 3, no. 5 (2014): 117-135.

${ }^{32}$ Handreas Hartono, "Kurikulum PAK Yang Kontekstual Bagi Usia Lanjut Dan Aktual," KURIOS (Jurnal Teologi dan Pendidikan Agama Kristen) 1, no. 1 (February 12, 2018): 11-21.

${ }^{33}$ Daniel Sutoyo, "Peran Roh Kudus Dalam Pemberitaan Injil," Jurnal Antusias 1, no. 3 (2011): $17-26$. 
Kristus. ${ }^{34}$ Pelayanan dengan karunia Roh akan membuat pertumbuhan gereja berkembang secara signifikan. ${ }^{35}$

Maka dari itu karunia rohani merupakan pemberian Tuhan kepada setiap orang percaya guna pelayanan-Nya. Sebagai mahasiswa STT Simpson, pemberdayaan karunia rohani ini sangat penting, sebagai upaya dalam mengoptimalkan pelayanan mahasiswa dalam gereja, sekolah maupun masyarakat. Mengingat pentingnya mengetahui karunia rohani, kelompok pembinaan juga menjadi wadah untuk membimbing mahasiswa mengenali karunia rohaninya. Beberapa dosen melakukan bimbingan pribadi untuk menolong mahasiswa mengenali karunia rohaninya. Cara lain yang dilakukan adalah dengan melakukan pengecekan kecenderungan karunia rohani berdasarkan teks 1 Korintus maupun literatur yang telah menyusun pedoman analisis.

Kesempatan untuk menyampaikan firman Tuhan, memimpin diskusi pendalam Alkitab, melayani rekan mahasiswa lainnya, mendoakan mahasiswa lainnya menjadi cara untuk mengasah karunia yang Roh Kudus telah berikan pada mahasiswa. Kesempatan yang diberikan oleh dosen sebagai pemimpin kelompok pembinaan merupakan langkah untuk mengasah karunia yang Roh Kudus telah berikan. Dengan demikian, kesempatan yang diberikan sepanjang masa perkuliahan akan semakin tampak dari masing-masing anggota binaan.

Keempat, konseling pribadidan grup. Bimbingan konseling merupakan suatu proses untuk membantu individu memecahkan masalah dalam hubungan antar pribadi, emosional dan pengambilan keputusan. Pembinaan juga memiliki peran tidak hanya bertumbuh dalam aspek pengetahuan tetapi juga bertanggungjawab terhadap aspek mendidik kepribadian, misalnya untuk disiplin, bertanggungjawab dan kemandirian. ${ }^{36}$ Setiap mahasiswa di STT Simpson memiliki pergumulan masing-masing, baik pergumulan biaya kuliah, perguluman terkait karakter pribadi mereka, hubungan dengan orang lain, dan berbagai persoalan yang membutuhkan konseling pribadi. Dari data administrasi yang dikumpulkan bidang akademik ditemukan mahasiswa yang masih ragu dengan keyakinan imannya pada Yesus Kristus. Hal tersebut tentunya perlu tindak lanjut melalui konseling pribadi yang dapat menolong mahasiswa lebih teguh pada keyakinannya. Selain itu, tantangan yang dihadapi mahasiswa dapat menyebabkan terjadinya kebimbangan mahasiswa pada panggilan pelayanan. Melalui konseling pribadi maupun grup, dosen dapat membimbing mahasiswa untuk lebih teguh menjalani panggilannya. Dalam menjalankan tugas ini, dosen dituntut untuk siap mendengarkan masalah mahasiswanya dan menahan diri untuk terlalu cepat memberikan solusi. Pola ini juga ditekankan oleh Juwita et al bahwa salah satu kompetensi dosen dalam menjalankan tugas perwalian sebagai konselor adalah siap mendengarkan dan memahami permasalah mahasiswa sehingga akhirnya dapat memberikan masukan untuk pemecahan masalah. ${ }^{37}$

Dalam hal ini perlu adanya sikap saling terbuka antara mahasiswa dan dosen pengampu kelompok pembinaan. Tujuannya membantu mahasiswa dalam mengatasi

${ }^{34}$ Peter Wagner, Manfaat Karunia-Karunia Roh Untuk Pertumbuhan Gereja (Malang: Gandum Mas, 1991). 40.

${ }^{35}$ Fereddy Siagian, "Fungsi Karunia-Karunia Roh Kudus Terhadap Pertumbuhan Jemaat Di Gereja Tiberias Indonesia Grand Mall Bekasi Barat," Syntax Literate : Jurnal Ilmiah Indonesia Vol. 3 No. 4 (April 2018).

36Sudjono, "Pentingnya Karunia Pengajar Di Dalam Gereja."

${ }^{37}$ Vera Angliani Juwita et al., "Pengembangan Kompetensi Dosen Wali: 'Aku Siap Mendengar Dan Memahamimu,'" in Prosiding Seminar Hasil Penelitian Dan Pengabdian Kepada Masyarakat Unjani Expo (Unex), vol. 1 (presented at the Seminar Hasil Penelitian dan Pengabdian kepada Masyarakat Unjani Expo (Unex), Cimahi: Unjani, 2020), 96-101, accessed April 9, 2020, http://journal.unjani.ac.id/index.php/unex/article/view/43. 
hambatan-hambatan dalam dirinya sendiri, baik hambatan belajar maupun kerohanian. Secara khusus mahasiswa STT Simpson yang berasal dari budaya dan latar belakang yang berbeda-beda, konseling pribadi dan grup sebagai upaya untuk memahami satu dengan yang lain. Perbedaan budaya dan latar belakang, juga mempengaruhi karakter dan perilaku mahasiswa. Secara kebutuhan dasar, mahasiswa perlu mendapatkan perhatian, kasih sayang bahkan penerimaan diri menjadi bagian dari kelompok.

Dosen dengan mahasiswa yang sedang menjalani masa disiplin kampus memperoleh tugas ekstra. Mahasiswa yang mengalami masalah karakter sehingga harus menjalani masa disiplin kampus memerlukan pendampingan dan bimbingan. Peran dosen wali dalam situasi ini adalah dengan menjadi konselor sehingga dapat membantu mengarahkan mahasiswa mengalami pertumbuhan rohani. Penelitian Purba menunjukkan bahwa pendekatan konseling yang mengarah pada proses pemuridan tampaknya dapat membantu mahasiswa mengalami pertumbuhan rohani. ${ }^{38}$

\section{Rekomendasi untuk Penelitian Lanjutan}

Dari proses penelitian, penulis mencermati perlu dilakukan penelitian lebih lanjut terhadap efektivitas pelaksanaan masing-masing kegiatan perwalian di STT Simpson. Pada aspek lain penulis juga merekomendasikan bagi peneliti lain untuk meneliti tingkat kepuasan mahasiswa terhadap pelaksanaan layanan perwalian terhadap mahasiswa. Rekomendasi untuk penelitian lanjutan adalah perlu penelitian terhadap pengaruh pelaksanaan perwalian untuk pembinaan rohani dan karakter terhadap pertumbuhan rohani mahasiswa. Tiga hal tersebut penulis pandang perlu diteliti lebih lanjut agar memperoleh informasi yang lebih komprehensif terkait kegiatan ini.

\section{Kesimpulan}

Dari hasil penelitian tampak bahwa di STT Simpson, perwalian terhadap mahasiswa dilaksanakan dalam dua bentuk yaitu bimbingan yang bersifat akademik dan bimbingan yang menekankan aspek kerohanian dan karakter. Perwalian untuk bimbingan akademik dilaksanakan melalui bimbingan rencana studi yang dilaksanakan dua kali dalam setiap semester. Bimbingan ini dilaksanakan untuk membantu mahasiswa merancang, memilih mata kuliah, dan menjalani perkuliahannya. Kemudian bimbingan akademik juga dilakukan melalui pemantauan mahasiswa perwalian sesuai dengan pola masing-masing dosen dan input dari dosen pengampu mata kuliah, sekretaris prodi, pengawas asrama, dan data dari BAAK. Perwalian akademik juga dilaksanakan dengan memberi motivasi agar mahasiswa mengalami peningkatan secara akademik. Kalimat dorongan maupun perhatian yang ditunjukkan oleh dosen wali bermanfaat dalam mendorong mahasiswa untuk lebih berhasil.

Selain bimbingan akademik, dosen juga memberikan bimbingan untuk pembinaan rohani dan karakter. Kegiatan ini dilaksanakan dengan kreatif dan sesuai kebutuhan masing-masing kelompok. Secara umum, dalam setiap kelompok pembinaan dilaksanakan doa bersama, bimbingan untuk mengenal karunia rohani masing-masing kelompok, konseling pribadi dan grup, dan pendalaman Alkitab. Semua hal itu dilaksanakan di STT Simpson sebagai sebuah upaya untuk pembinaan rohani dan pembentukan karakter seorang pengerja rohani.

${ }^{38}$ Asmat Purba, "Metode Pelayanan Yang Tepat Dalam Pertumbuhan Iman Mahasiswa Kristen Di Politeknik TEDC Bandung," Jurnal TEDC 8, no. 3 (September 9, 2019): 248-253. 


\section{Rujukan}

Amba, Oktavia. "Implementasi Pemuridan Kontekstual Untuk Meningkatkan Minat Remaja Kristen Dalam Membaca Alkitab." IAKN Tooraja, 2020. Accessed April 8, 2020. https://osf.io/q54ra/.

Anidar, Jum. "Peran Penasehat Akademik Terhadap Kesuksesan Mahasiswa di Perguruan Tinggi." Al-Ta lim Journal 19, no. 3 (November 21, 2012): 216-223.

Anirah, Andi. "Mekanisme Layanan Bimbingan Akademik Dalam Meningkatkan Motivasi Belajar Mahasiswa Di Institut Agama Islam Negeri Palu." Istigra: Jurnal Hasil Penelitian 4, no. 1 (2016): 49-80.

Antarini, Lilik, I. Nyoman Mangku Suryana, and I. Wayan Sudemen. “Tingkat Kepuasan Layanan Mahasiswa Universitas Warmadewa Tahun 2017." SINTESA (Jurnal Ilmu Sosial dan Ilmu Politik) 8, no. 1 (2017): 12-16.

Ariska, Ita. "Peran Dosen Pembimbing Akademik dalam Meningkatkan Motivasi Belajar Mahasiswa: Penelitian Di Fakultas Dakwah dan Komunikasi Universitas Islam Negeri Sunan Gunung Djati Bandung Angkatan 2012." Diploma, UIN Sunan Gunung Djati Bandung, 2015. Accessed April 9, 2020. http://digilib.uinsgd.ac.id/5145/.

Asriati, Nuraini, and Muhammad Basri. "Profil Kinerja Dosen Jurusan Pendidikan IPS FKIP Untan." Guru Membangun 30, no. 1 (2015): 35-45.

Brill, Wesley. Dasar Yang Teguh. Bandung: Kalam Hidup, 2015.

Creswell, John W. Research Design: Pendekatan Kualitatif, Kuantitatif, Dan Mixed. Yogyakarta: Pustaka Pelajar, 2013.

Darmawan, I. Putu Ayub. "Murid Yang Memuridkan." In Melaksanakan Amanat Agung Di Abad 21. Ungaran: Sekolah Tinggi Teologi Simpson, 2017.

Darmawan, I. Putu Ayub, and Edi Sujoko. "Survei Terhadap Kepuasan Mahasiswa Pada Kualitas Layanan Di STT Simpson Ungaran, Semarang, Jawa Tengah." Satya Widya 33, no. 1 (2017): 45-53.

Hartono, Handreas. "Kurikulum PAK Yang Kontekstual Bagi Usia Lanjut Dan Aktual." KURIOS (Jurnal Teologi dan Pendidikan Agama Kristen) 1, no. 1 (February 12, 2018): 1121.

Juwita, Vera Angliani, Chandra Yudhistira P, Defri Sefianni, and Niken Cahyorinartri. "Pengembangan Kompetensi Dosen Wali: 'Aku Siap Mendengar Dan Memahamimu.'" In Prosiding Seminar Hasil Penelitian Dan Pengabdian Kepada Masyarakat Unjani Expo (Unex), 1:96-101. Cimahi: Unjani, 2020. Accessed April 9, 2020. http://journal.unjani.ac.id/index.php/unex/article/view/43.

Katarina, K., and I. Putu Ayub Darmawan. "Implikasi Alkitab Dalam Formasi Rohani Pada Era Reformasi Gereja." EPIGRAPHE: Jurnal Teologi dan Pelayanan Kristiani 3, no. 2 (2019): 81-93.

Patimah, Siti. "Hubungan Peran Bimbingan Akademik, Kecerdasan Intelektual, dan Minat dengan Prestasi Belajar." Media Informasi 11, no. 1 (July 1, 2015): 20-26.

Purba, Asmat. "Metode Pelayanan Yang Tepat Dalam Pertumbuhan Iman Mahasiswa Kristen Di Politeknik TEDC Bandung." Jurnal TEDC 8, no. 3 (September 9, 2019): 248253.

Purwanto, Hary. "Manfaat Penelitian Untuk Perkembangan Gereja." In Prosiding Seminar Nasional Pendidikan Agama Kristen STT Simpson Tahun 2016 Tema: Strategi Pembinaan Jemaat Untuk Meningkatkan Kehidupan Jemaat. Ungaran: Sekolah Tinggi Teologi Simpson, 2016.

Rice, Howard. Manajemen Umat. Bandung: Kalam Hidup, 2006.

Riniwati, R. Motivasi, Prestasi Dan Evaluasi Belajar. Ungaran: Sekolah Tinggi Teologi Simpson, 2016. 
Rizki, Mohammad. “Evaluasi Terhadap Efektifitas Pembimbingan Online Untuk Perwalian Mahasiswa Jurusan Kurtedik, FIP, UNNES." Other, Universitas Negeri Semarang, 2015.

Rizki, Mohammad Tri. "Evaluasi Terhadap Efektivitas Pembimbingan Online Untuk Perwalian Mahasiswa Jurusan Kurtekdik, FIP, UNNES." Under Graduates thesis, Universitas Negeri Semarang, 2015. Accessed April 6, 2020. https://lib.unnes.ac.id/23199/.

Saifudin, M. Fakhrur. "Pola Pembimbingan Akademik Dosen Wali Sebagai Upaya Efektivitas Masa Studi Mahasiswa." JMKSP (Jurnal Manajemen, Kepemimpinan, dan Supervisi Pendidikan) 3, no. 2 (2018): 149-160.

Selan, Ruth. Pembinaan Warga Gereja. Bandung: Kalam Hidup, 2006.

Siagian, Fereddy. "Fungsi Karunia-Karunia Roh Kudus Terhadap Pertumbuhan Jemaat Di Gereja Tiberias Indonesia Grand Mall Bekasi Barat." Syntax Literate: Jurnal Ilmiah Indonesia Vol. 3 No. 4 (April 2018).

Simanjuntak, Junihot M. "Implikasi Konsep Dan Desain Kurikulum Dalam Tugas Pembinaan Warga Jemaat." Jurnal Jaffray 12, no. 2 (October 2, 2014): 251-272.

Sianturi, RJ Natongam, and Hasudungan Sidabutar. "Perilaku Seksual Pranikah Di Kalangan Mahasiswa Program Studi Pendidikan Agama Kristen." Jurnal Ilmiah Religiosity Entity Humanity (JIREH) 1, no. 1 (June 18, 2019): 72-86.

Sudjono, Andreas. "Pentingnya Karunia Pengajar Di Dalam Gereja." Jurnal Antusias 3, no. 5 (2014): 117-135.

Sulistio, Thio Christian. "Peran Roh Kudus di dalam Doa menurut John Calvin." Veritas: Jurnal Teologi dan Pelayanan 2, no. 2 (October 1, 2001): 177-184.

Suma, Enang, and Aan Sukandar. "Efektivitas Pelaksanaan Bimbingan Perwalian Terhadap Sikap Belajar Mahasiswa Pendidikan Teknik Mesin FPTK UPI Bandung." file.upi.edu (n.d.). Accessed April 2020. https://www.academia.edu/1173062/EFEKTIVITAS_PELAKSANAAN_BIMBINGA N_PERWALIAN_TERHADAP_SIKAP_BELAJAR_MAHASISWA_PENDIDIKAN_TE KNIK_MESIN_FPTK_UPI_BANDUNG.

Sutoyo, Daniel. “Allah Memanggil Umat-Nya Untuk Menjadi Gereja Yang Tekun Berdoa Menurut Kisah Para Rasul 4: 23 - 31." DUNAMIS: Jurnal Teologi dan Pendidikan Kristiani 1, no. 1 (September 1, 2016): 52-73.

- - - "Peran Roh Kudus Dalam Pemberitaan Injil." Jurnal Antusias 1, no. 3 (2011): 17-26.

Wagner, Peter. Manfaat Karunia-Karunia Roh Untuk Pertumbuhan Gereja. Malang: Gandum Mas, 1991.

Zaluchu, Sonny Eli. "Strategi Penelitian Kualitatif dan Kuantitatif Di Dalam Penelitian Agama." Evangelikal: Jurnal Teologi Injili dan Pembinaan Warga Jemaat 4, no. 1 (January 31, 2020): 28-38. 